阿賀沖プラットフォームからの開発井の掘さくについで*

竹 田幸 平*.小林 秀 隆*

日本海洋石油資源開発㑣と出光日本海石油開発(㑣は昭 和46年11月初旬から昭和 48 年 3 月初旬に渉って新潟市の 沖合で 6 坑井の試掘を行ない，東西 2 構造から成る集油 集ガス構造を発見した。本試掘結果について検討が行な われ，東西両構造の中間点汇ドリリング プロダクショ ンプラットフォームを建造して東構造に対して 4 坑井, 西構造に対して 8 坑井, 合計12坑井を掘さくすることが 決定された。プラットフォームの建設は阿賀野川河口約 $11 \mathrm{~km}$ の沖合, 水深 $80 \mathrm{~m}$ の地点 $\left(\mathrm{N} 38^{\circ} 02^{\prime} 57^{\prime \prime}, \mathrm{E} 139^{\prime} 34^{\prime \prime}\right)$ で昭和 49 年 5 月中旬から 8 月下旬までの間に行なわれ, 新日本製鉄㑣の響難ヤードで建造されたジャケット部と 日本鋼管(株津造船所で建造された上部構造が組み立られ た。プラットフォームからの開発井の掘さくは昭和 49 年 8 月下旬より開始され現在まで 7 坑井の掘さくが終了し ているが，掘さく作業の進展にともない地質構造の再検 討が行なわれ，頭初の計画坑数 12 坑に 2 坑が追加され， 昭和51年 2 月に掘さくが終予することになるている。掘 さく終了後まとめて全坑井の仕上打よびプロダクション テストが行なわれ，昭和51年 8 月より生産が開始される 予定である。

以下阿賀沖プラットフォームからの開発井の掘さくに ついてその概要を述べる。

\section{1. 掘さく作業の概要}

開発井のケーシング プログラは 30 in $\times 20$ in $\times 13 \frac{3}{8} /$ in $\times 9 \frac{5}{8}$ inであり, 30 in コンダクタ パイプはプラットフォ 一ム建設時にあらかじめ海底面下 $50 \mathrm{~m}$ まで打込まれて いる。一方プラットフォームのセラ フロアの一觕には BOPアッセンブリ用の架台が設けられて和り，20-2,000 BOP アッセンブリ (Fig. 1) と 135/8-5,000BOP アッ センブリ（Fig. 2) があらかじめ組立てられている。

(1) 30 in コンダクタ パイプに20-2,000BOPアッセン ブリを取り付け（Fig. 3)，350mまで $12 \frac{4}{4} / \mathrm{in}$ たは $17 \frac{1}{2}$ inのパイロットホールを掘進する。これは阿賀沖地域 に存在するシャロー ガスの噴出に対処するための処置 であり,パイロットホール掘進中にガスが噴出した場合 には，BOPを締めて貲出ガスをデパート ラインより放 散させつつ重泥を送る等してウェル コントロールを行 ならためである。

* 日本海洋石油資源開発㑣

** 第40回石油技術協会総会シンポジウムさく井部門满演 (昭和50作 6 月27日)

石油技術協会誌, Vol.40 No.7 (1975)
(2) パイロットホール掘進中に異常がなかったら BJP アッセンブリーを取り外し，代りに30inベルニッ プルを取り付けて 26 in坑に拡掘する。

(3） 20 inケーシングを降下しセメンチングする。20in ケーシングのセメントは完全に坑口まで充填されるもの とし，もしプライマリセメンチングで坑口までセメント が上昇しない場合には，30in コンダクタパイプと 20 in ケーシングの間陌に1.9inチュービングを降下しトップ ジョブにより完全に坑口までセメントを充垻する。

Fig. 1 20-2000 BOP アセンブリ

1: HYD (MSP) 20-2000

2: CAM (U) 20-2000

3: DRLG SPOOL 20-2000

4: 20 in CSG HEAD

5: 20 in SQUANCH JOINT "ATD"

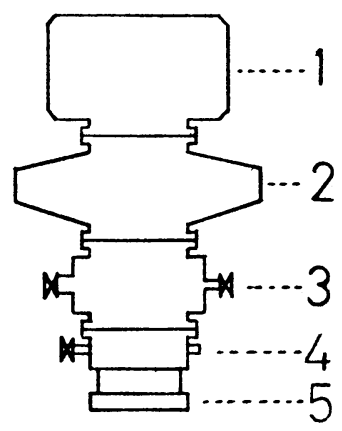

Fig. 2 135/8in-5000 BOP アセンブリ

1: $\mathrm{HYD}(\mathrm{GK}) 13 \% / 8 \mathrm{in}-5000$

2: CAM(U-DOUBLE) $135 / 8 \mathrm{in}-5000$

3: DRLG SPOOL $13 \% / 8 \mathrm{in}-5000$

4: 2in CHECK VALVE

5: 2in GATE VALVE

6: 4in GATE VALVE

7: 4in HYDLAULIC OPERATED VALV:

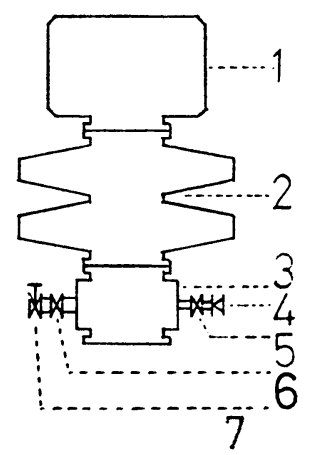


Fig. 3 パイロットホール掘進用坑口装置

1: 20 in VEIL NIPPLE

2: HYD(MSP) 20-2000

3: $\mathrm{CAM}(\mathrm{U}) 20-2000$

4: DRLG SPOOL 20-2000

5: 20in CSG HEAD

6: 20in SQUANCH JOINT "ATD"

7: 6in DIVERT LINE

8: 20 in $\times 30$ in REDUCER

9: 30in SQUANCH JOINT "ALT"

10: 30 in CONDUCTOR

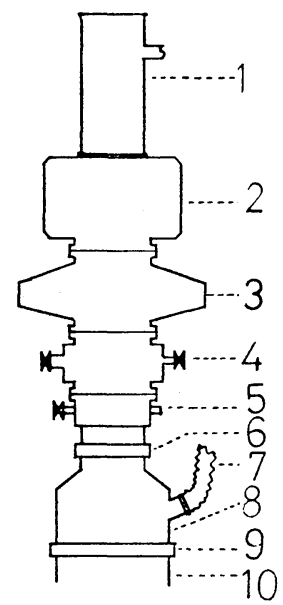

(4) セxントが硬化したら，20inケーシング頭部のス カンチ ジョイントより吊管を切り離し20in BOPアッセ ンブリを取り付ける(Fig. 4)。

(5) $20 \mathrm{in}$ ケーシング シュー下 $30 \mathrm{~m}-50 \mathrm{~m}$ も KOP とし て傾斜掘を行ないつつ $13 \%$ in ケーシング降下予定深度ま で12 in坑を掘進する。

(6) 電検を行なら。

(7) 17 in坑拨掘する。

(8) $13 \frac{3}{8}$ in ケーシングを降下してセメンチングする。 $13 \frac{3}{8} \mathrm{in}$ ケーシングのアニニラス部をできるだけ外くセメ ントで充填するために，セメンチングは 3 ステージで行 なう。20inケーシング内シュー上直上にECP（エクスタ ーナル ケーシング パッカ）をセットすることにより 20 inケーシングと $13 \frac{3}{8} / \mathrm{in}$ ケーシングの間隙を完全にセメン トで充媜する。

（9）セメントが硬化したら 20-2,000 BOP アッセンブ リをスカンチ ジョイントより切り離して吊り上げ，13 $3 / 8$ inケーシングをセラ フロア面で切断し， $13 \frac{3}{8} / 8$ in ケー シングに $13 \frac{3}{8} / 5-5,000$ カメロン“TD” コンパクトヘッド を溶接し，さらに 135/8-5,000 BOP アッセンブリを取り 付ける (Fig. 5)。

(10) $12 \frac{1}{4}$ in坑を予定深度をで掘進する。

(11) 電検する。

(12) $95 \%$ in ケーシングを降下しセメンチングを行なっ
Fig. 4 20inケーシング坑口装置

1: 20 in VEIL NIPPLE

2: HYD(MSP) 20-2000

3: CAM(U) 20-2000

4: DRLG SPOOL 20-2000

5: 20in CSG HEAD

6: 20 in SQUANCH JOINT "ATD"

7: 20 in CSG

8: 30 in CONDUCTOR

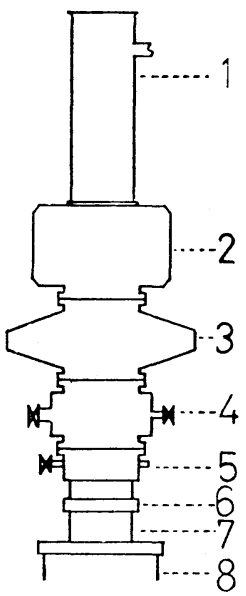

Fig. $513 \frac{3}{8}$ inケーシング坑口装置 1: VEIL NIPPLE

2: $\mathrm{HYD}(\mathrm{GK}) 135 / 8 \mathrm{in}-5000$

3: CAM(U-DOUBLE) $13 \frac{5}{8} \mathrm{in}-5000$

4: DRLG SPOOL $135 / 8 \mathrm{in}-5000$

5: COMPACT HEAD (CAM "TD") $13 \frac{5}{8}$ in -5000

6: $13 \frac{3}{8}$ in CSG

7: 20 in CSG

8: 30 in CONDUCTOR

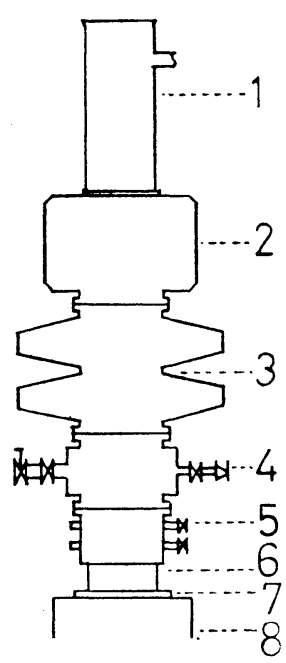


た後、シールアッセンブリを取り付ける。

(13) 坑口から BOP アッセンブリを取り外し坑口に保 護カバを取り付け，次井に移動する。

(14) 全坑井の掘さくが終了したら下記の組み合せのい ずれかで仕上を行なう。

(i) $1-2 \frac{7}{8}$ inストリング， 1 シングルパッカ仕上

(ii) $1-2 \frac{7}{8}$ inストリング, 2 シングル パッカ仕上

(iii) $2-2 \frac{7}{8}$ inストリング, 1 シングル パッカ, 1 ジ コアルパッカ仕上

(iv) $2-7 \frac{7}{8}$ inストリング， 1 シングル バッカ， 2 ジ ュアル パッカ仕上

2. セメンチングについて

\section{2-1 セメンチングの概要}

(1) 20 inケーシング セメンチング

フルホールセメンチングを行う。もしプラマリー セメンチングで坑口までセメントが上䒜しない場合に は, 30 in コンダクターパイプと 20 in ケーシングの間隙

Fig. $613 \frac{3}{8}$ in ケーシング降下

1: AUTO-FILL UP SHOE

2: AUTO-FILL UP COLLAR

3: BY-PASS BAFFLE

4: SHUT OFF BAFFLE

5: CEMENT BASKET

6: LOWER DV CEMENTER

7: 20 in CSG SHOE

8: ECP

9: UPPER DV CEMENTER

10: $13 \% \frac{3}{8}$ in 61 PPF $\mathrm{N}-80 \mathrm{CSG}$

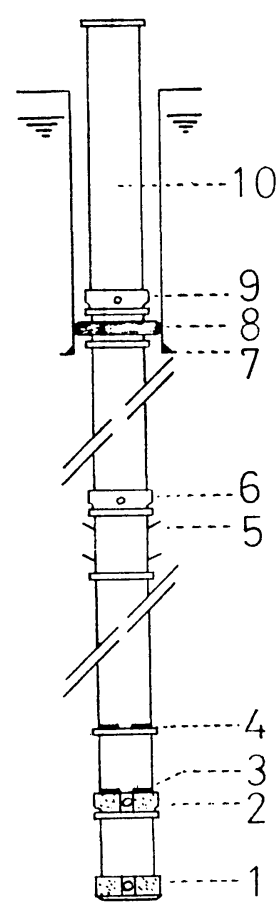

に1.9inチュービングを降下しトップジョブにより完全 に坑口までセメントで充填する。

(2) $13 \frac{3}{8}$ in ケーシング セメンチング( Fig. 6 )

3 ステージ セメンチングを行ない, $13 \frac{3}{8}$ inケーシン グ アニュラス部をできるだけ多くセメントで充媜する。 頭初の計画では $13 \frac{3}{8}$ in ケーシング アニュラス部を完全 にセメントで充填する予定であったが，後述する DV七 メンターのトラブルのため計画を変更しローアーDVッ 一ルを坑井傾斜角度30度以下の所に使用している。この ため 1st ステージと 2nd スデージの間にセメントで充填 されない部分が生じている。

(2)- i ） 1stステージ：ニートセメントを使用する。

(2)- ii ） 2nd ステージ：セメントは充填物として使用 され圧縮強度は必要としない。D-792\%セメントをSG 1.50で溶解する。

(2)- iii ） 3rd ステージ：セメントは $13 \frac{3}{8} /$ in ケーシング および 135/8-5,000 BOP アッセンブリ一の重量を支持す る圧縮強度を有し, かつ早期にその強度を発現する必要 があり, ニートセメントを使用する。20inケーシングシ ュー下の地層の強度を考慮して20inケーシング内シュー 直下に $13 \frac{3}{8}$ in ECP をセットする。

(3) $95 / 8$ inケーシング セメンチング (Fig. 7 )

頭初 2 または 3 ステージによるフル ホールセメンチ ングが計画されたが，DVセメンターに欠陥が発見され たためDVセメンターの使用を中止し，D-79 1.5\%七 メントを先行セメントとする 1 段セメンチングによるフ ルホールセメンチングが試みられた。この場合 D-79セ メントは充填物およびスカベンジング スラリーとして 使用され SG 1.45-1.50 で溶解されたが，先行する D-79 セメントと後行するニートセメントの境界面で両者が混 じり合ってセメント液の組成が変わり, シックニング タ イムがラボテストに拈けるものより大幅に縮まる危険 があることがわかったので，本法方は中止された。結局 フルホールセメンチングは断念され, DV を坑井傾斜 角度 30 度以下の所に使用して 1st ステージで裸坑部分 を，2nd ステージで坑口部分をセメンチングすることに している。

\section{2-2 セメンチングに関する問題点}

(1) DV セメンターに関する問題

$13 \frac{3}{8}$ in ハリバートン社の DVセメンターを使用して 2 または 3 ステージで完全なフル ホール セメンチングを行ならべ く計画された。しかしDVセメンターに関して次のよう な問題点が発見されたので, 現在ではDVセメンターを 坑井傾斜角度30度以下の所に使用することにており，フ ルホール セメンチングは断念している。 
Fig. $7 \quad 9 \frac{5}{8}$ inケーシング降下

1: AUTO-FILL UP SHOE

2: FLOW CONTROL FLOAT COLLAR

3: BY-PASS BAFFLE

4: SHUT OFF BAFFLE

5: $13 \frac{3}{8}$ in CSG SHOE

6: ECP

7: DV CEMENTER

8: $95 / 8$ in $47 \mathrm{PPF} \mathrm{N}-80 \mathrm{CSG}$

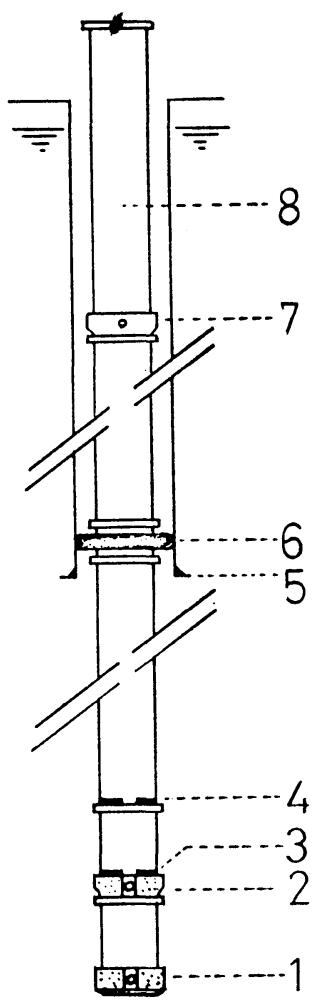

1）坑井傾斜角度 30 度以上の所にDVセメンターを使 用すると，1st ステージのセメント後押中にシャッ トオフプラグが DVセメンターに引っ掛って DV セメンターを通過しない。

ロ）このため $1 \mathrm{st}$ ステージの後押終了をポンプ圧力の 上蒋によって確認できず,オーバーデスプレースを 起こしやすい。

八) DV ポートを開口するためにオープニング ボム を投下しても DVに引っ掛っているシャットオフ プラグのためにDVにボムが正しくシートせず, こ のためDVセメンターのポートの開口が不可能とな り, DVセxンターからのステージ セxンチング ができなくなる。

(2) $95 / 8$ inケーシング セメントのボンデングに関する 問題

これまでセメンチングされた $9 \frac{5}{8}$ in ケーシングについ
て CBL-VDL を行なったが，一般にそのポンデングは プアーであることが判明した。現在プアーポンドを示 す CBL について 2 通りの解訳が考兄られている。

イ）マイクロアニュラスのために見掛上プアーボン デングに見える場合

この場合見掛上プアーボンデングであるが必要な ハイドロリックシールは得られるので，スクイズ セメンチングの必要はない。今後マイクロアニュ ラスかぞうか判定するために，ケーシングを加圧し た状態で同じケーシングに対して再度 CBL を行な ってみる予定である。もし测定された CBL のアン プリチュードが最初に測定された CBL のアンプリ チュードより小さくなっていれば, プアーボンデン グの原因はマイクロアニュラスといらことになり スクイ ズセメンチングは不必要になる。

ロ）セメントボンドが実際にプアーである場合 この場合には必要なハイドロリックシールを得る ためにスクイズ セメンチングをすることが必要に なる。セメントボンドが実際にプアーになる原因 としてまずセメントチャンネリングが考えられる。 開発井の坑井傾斜角度は 30-50 度の高傾斜であり, 仕上対象層に対しては 1 ジョイント当り 1 組, それ 以外の裸坑部分に対しては 5 ジョイント当り 1 組の セントラライザーを使用しているが，高傾斜のため ケーシングが坑井のローサイドと接触してセメント 後押時にローサイド側で泥水とセメントスラリー の置換が行なわれず，このためチャンネリングが起 ると考える。

セメント ボンドを改善するには, セントラライザー 扎よびスクラッチャーを使用してセメント後押中に ケーシングを管動しセメントチャンネリングを防 止することが最善と考えられるが，本開発井のよう な高傾斜井にお敃管動は管動中のケーシング抑留 等の事故が心配されるので, 今後は先行セメントの 種類およびセメント スラリーのフローパターンを 変えることによりボンドの改善を計りたいと考えて いる。

\section{3. 傾斜掘について}

本プラットフォームは東西両構造の中間点に設置され ているため，すべての坑井は 30-50 度の坑井傾斜で計画 されて拈り，20in ケーシング シュー下 30-50m の点を KOP として $10 \mathrm{~m}$ につき 1 度の増角率で傾斜掘が行なわ れている。最初の傾斜掘はキックオフおよび増角をジ ェッテング ビットによるスパッデングで行ない, スパッ デングによる方位のコントロールが困難な場合にダイナ ドリルを使用した。しかしスパッデングによる傾斜掘に 
は次のような問題があるので, 現在はキックオフの時点 からダイナドリルを使用している。

（1）スパッデングによった場合には地層の硬さが均一 でないと硬い地層の所で大きく增角しドグレッグとな り,傾斜角度矯正のための浚渫が必要になることがある。

(2) スパッデングを行ならとスウェベル等の機器を損 傷する恐れがある。

(3) ダイナドリルによる増角の方がドグ レッグを作 らないで坑井の軌跡が滑らかになり電検ツールスの不降 下等のトラブルが少なくなる。

(4) ダイナドリルの使用料金を考慮した場合でも作 業時間が短縮されるので, ダイナドリルの方が有利であ る。

\section{DST について}

プラットフォームでは原則として全坑井掘さく終了後 にまとめてプロダクションテストを実施することにな っているが，もし掘さく中に油層評価上必要を生じた場 合には $95 / 8$ in ケーシングの中で DST を行ならことにな っている。

\section{4-1 DST の方法}

セメントレテーナーをセットしてFig 8 亿示す編成 でPCTを降下しテストを行なう。PCTは従来の MFE の上部に接続して降下され, 降下後 BOP を締めて外圧 に加圧することによりバルブが開放となり，外圧を払う とバルブが締まる。外圧の加圧, 解放の繰返しにより何 回でもバルブの開閉が可能となり,このため従来の $\mathrm{MFE}$ が持っていた次のような欠点が改良された。すなわち MFEのバルブ開閉操作はテスト ストリングの上下動 によってなされ，バルブ開閉の確認はフリーポイント のチェックによってされるが

(1) 高傾斜井ではフリーポイントをインジケーター から読みとることは困難である。

(2) フローターまたはセミサブマーシブル バージか らの MFE では，海が荒れている場合，船体の上下動の ためにフリーポイントがつかみにくくバルブ開閉の確 認が困難である。

(3) フローターまたはセミサブマーシブル バージか ら MEEのでは，また海が荒れている場合には，フロー またはシャットインのためのストリングの掍げ降げ時 に誤ってパッカーまたはステンガーの腰切りが起る恐れ がある。

4-2ＤSTまたはプロダクション テストの安全対策

DST またはプロダクション テスト時には次のような 安全対策を行なう。

(1) 気象データの集収および検討

パーフォレーション実施の前日より，每日 1 回以上気
Fig. 8 DST

1: $95 / 8$ in CSG

2: PERFORATION

3: CEMENT RETAINER

4: STINGER

5: RECORDER

6: RECORDER

7: OPEN HOLE BY-PASS

8: MFE

9: DCT

10: BAR CATCHER

11: SLIP JOINT

12: HEAVY WEIGHT DRILL PIPE (3 STDS)

13: PUMP OUT SUB

14: HEAVY WEIGHT DRILL PIPE (3 STDS)

15: BREAK OUT SUB

16: 5in DRILL PIPE

17: CONTROL HEAD

18: OIL BURNER

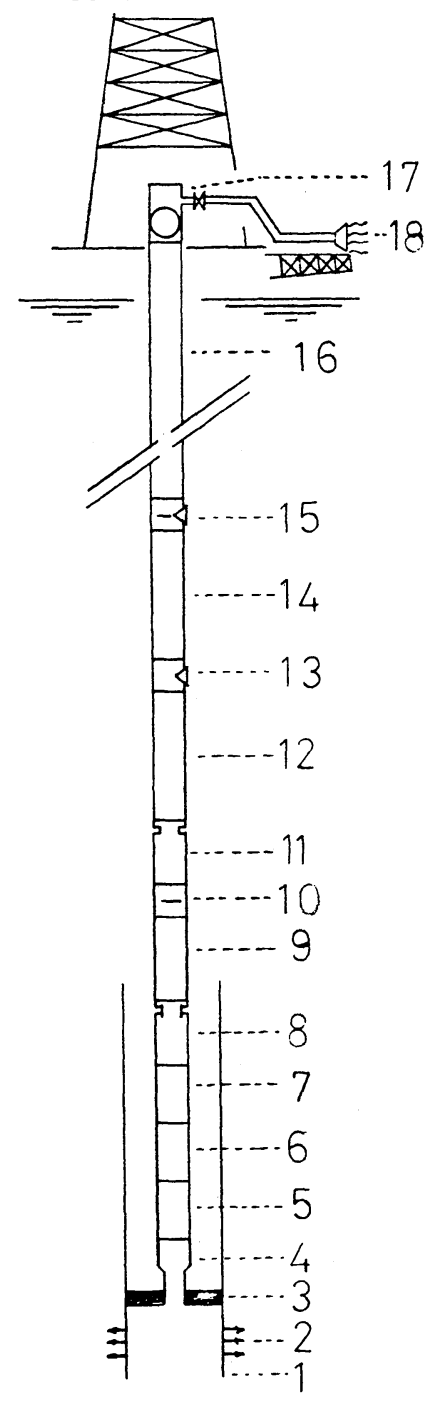


象データを入手し48時間の気象予報について検討する。 もしテスト予想時間中に $30 \mathrm{~m} / \mathrm{sec}$ 以上の風速が予報され ている場合には，パーフォレーションを中止しテストを 延期する。またテスト中にも常時気象観測を行なって, もしフロー中に風速が $25 \mathrm{~m} / \mathrm{sec} を$ 超光たらフローを中止 しシャットインする。これは風速が $30 \mathrm{~m} / \mathrm{sec} を$ 超える と甲板上の人の歩行が危険で作業を中止する必要があ り，また風速 $25 \mathrm{~m} / \mathrm{sec}$ 以上となると急激な風向の变化に よりオイルバーナーの炎がプラットフォームに被る恐 れがあるからである。

(2) ファイヤードリルの実施

セカンドフロー開始前にファイヤードリルを行な う。

（3）セカンドフローの開始は日中に行なう。これは 日中にセカンドフローを開始することにより地表装置 の漏洩で早期に発見でき，また漏洩があっても照明等か ら漏洩した油やガスに引火して火災が発生するという危 険を除去するためである。

(4) セカンドフロー中は，スタンド バイ ボートが アンカーを掲げプラットフォーム付近の風上側に待機す る。これはテストストリングの損傷や地表装置の漏洩 により地層流体をコントロールできなくなったり火災が 発生したりして，プラットフォームから余㷣なく退避せ ねばならない場合に備えたものである。

(5) 鉱害の監視抢よび防止

プラットフォーム扣よびスタンド バイ ボートには油 乳化剂拉よびオイルフェンスを何時でも使用できる状 態で準備しておく。一方テスト中は専門の鉱害監視者を 1 名指名し，本監視者が常にプラットフォーム上を巡回 乙て油・泥等の漏洩流出の発見に努める。

\section{4-3 生産物の処理}

DST またはプロダクションテストで生産された流体 は地表装置で計量された後オイル バーナ一で直ちに然 焼される。オイルバーナーは 60-70\%の泥水または水を 含む油の燃焼も可能であり，テスト中に生産される数 10 $\mathrm{k} l$ に及ぶ油を鉱害を出すことなく安全確実に処理するこ とができる。

\section{5. 防噴対策}

海洋掘さくに护けるブローアウトの発生は人命と財 産に重大な損害をもたらすこことがあるので，防噴対策に は力を入れ下記のようなクルーの訓練と BOP の点検を 充分に行なっている。

(1) 防噴訓練

i ）掘進時の毎日各交代 1 度のピットドリル

ii）掲管時のインサイド BOP ドリル

iii） セメンチング終了, BOP取付時のケーシング内
にお汻る ABCバルブーチョーク マニホールドを 使用しての BOP ドリル

(2) BOP の点検

i ）BOP架台における BOP アッセンブリーの清掃 目視点検

ii) BOP取付時の BOP 作動テスト，加圧テスト， BOP 開閉装置の作動テストセメンチング線およ び泥水各線のワーキングプレッシャーまでの加 圧テスト。

iii) 掘さく中の掲管時の BOP 作動テスト

\section{6. 保安対策}

プラットフォームの保安対策としてプラットフォーム 安全基準が設けられて抒り，プラットフォーム上の保安 組織, 各作業に和计る遵守事項, 各作業員の作業分担, 保安義務，消火および緊急退避訓練等について規定され ている。とくに万一の場合に人命を守るために，10日ご と消火訓練, 緊急退避訓練, 溺者救助訓練, 救命艇降 下訓練のいずれか，またはこれらのらちのいずれかを組 み合せて訓練を行ない，同時に消火器および救命具の点 検を行なっている。

\section{7. その他}

\section{7-1 気象観測之気象予報}

プラットフォームにはあらゆる気象，海象を自動的に 観測し記録する装置が設備されており，常時気象観測を 行なっている。

気象予報の入手は夏期には通常プラットフォームに設 備されているファクシミリ，テレビ，ラジオ等から入手 するが，台風等が接近する場合には新潟気象台から入手 する。とくに海の荒れる冬期（10月～3月）には，気象 コンサルタントがプラットフォーム纪常駐し 1 日 2 回以 上の予報を行なう。

\section{7-2 気象とプラットフォームにおける作業}

気象，海象はプラットフォームに打ける作業自体には 大きな影響は与兄ない。風速が $25 \mathrm{~m} / \mathrm{sec}$ を超えると揚降 管作業が危険となり，30 $\mathrm{m} / \mathrm{sec}$ を超えると甲板上の歩行 が危険となるので，揚降管作業を中止し甲板上の歩行を 禁止するが，その他の作業は風速に関係なく続行できる ので荒天による待機は少なく，昭和49年10月から昭和50 年3月までの間の天候待機時間の合計は11時間であった。

\section{7-3 気象海象と資材のサプライ}

資材のサプライは750 t と500 t の 2 隻のサプライ ボ

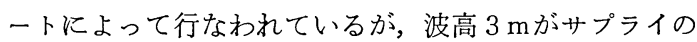
限界である。一方上記の如くプラットフォームに拈ける 作業は天候により制限されることは少なく作業の続行は 可能であっても，資材のサプライとくにドリル ウォータ 一のサプライの面から制限されることが多い。 